\title{
Prefabricated Plug-and-Play Unitized Façade System for Deep Retrofitting: The RenoZEB Case Study ${ }^{\dagger}$
}

\author{
Alessandro Pracucci ${ }^{1, * \mathbb{D}}$, Laura Vandi ${ }^{1}$, Sara Magnani ${ }^{1}$, Alessia Baietta ${ }^{1}$, Oscar Casadei ${ }^{1}$, Amaia Uriarte ${ }^{2}$ and \\ Michele Vavallo ${ }^{3}$
}

1 Focchi S.p.A., Via Cornacchiara, 47824 Rimini, Italy; 1.vandi@focchi.it (L.V.); s.magnani@focchi.it (S.M.); a.baietta@focchi.it (A.B.); o.casadei@focchi.it (O.C.)

2 Tecnalia Research \& Innovation, Parque Tecnológico de Bizkaia, Astondo Bidea, Edificio 700, Derio, 48160 Bizkaia, Spain; amaia.uriarte@tecnalia.com

3 R\&D Department, Solintel M\&P S. L. Avda. de la Industria n. 4, Edificio 1, Oficina 1B, 28108 Madrid, Spain; michele.vavallo@solintel.eu

* Correspondence: a.pracucci@focchi.it

† Presented at the Sustainable Places 2021, Rome, Italy, 29 September-1 October 2021.

Citation: Pracucci, A.; Vandi, L.; Magnani, S.; Baietta, A.; Casadei, O.; Uriarte, A.; Vavallo, M. Prefabricated Plug-and-Play Unitized Façade System for Deep Retrofitting: The RenoZEB Case Study. Environ. Sci. Proc. 2021, 11, 9. https://doi.org/ 10.3390/environsciproc2021011009

Academic Editor: Zia Lennard

Published: 25 November 2021

Publisher's Note: MDPI stays neutral with regard to jurisdictional claims in published maps and institutional affiliations.

Copyright: (C) 2021 by the authors. Licensee MDPI, Basel, Switzerland. This article is an open access article distributed under the terms and conditions of the Creative Commons Attribution (CC BY) license (https:// creativecommons.org/licenses/by/ $4.0 /)$.

\begin{abstract}
The retrofitting of the existing building stock is one of the most important goals to be pursued to meet European targets. In this context, the RenoZEB project has developed a modular methodology for the deep retrofitting of buildings, which is enabled by a prefabricated plug-and-play façade that integrates different on-market technologies to achieve nZEB standards. This article reports on the activities conducted in the study and design of the RenoZEB prefabricated envelope system, providing insights on the tests conducted and the results achieved for the façade system, with a specific focus on the use of technology laboratory facilities for real-environment validation, which revealed the system to be in line with the project objectives.
\end{abstract}

Keywords: plug-and-play façade; energy consumption; building retrofitting

\section{Introduction}

In the construction sector, the retrofitting of the existing building stock is one of the most important aspects in fulfilling the European targets for carbon footprint and energy reductions. The target of the renovation of $3 \%$ of the existing building stock annually by 2030 is far from being achieved, with current only $1 \%$ of building being renovated yearly. The reason for this is that the traditional solutions are expensive, complex, disruptive, and highly time-consuming, with inherent inefficiency [1]. The objective of the RenoZEB project [2] is to adopt a holistic methodology to face these challenges, along with the development of plug-and-play (P\&P) façades that can be unitized and prefabricated, integrating different on-market technologies to achieve nZEB standards. The present article highlights the results achieved in the P\&P façade analysis design, prototyping, and validation activities during the RenoZEB project.

\section{Methodology}

Based on the selection of the on-market technologies to be integrated into the façade system and the analysis of the existing building boundary conditions [3], the methodology for the façade system development was divided into different phases:

1. Design phase-The objective is to design the P\&P façade by working on existing buildings in a less intrusive way so as not to affect users or daily activities while providing a deep retrofitting solution for the building envelope;

2. Prototype phase-The objective is to manufacture the P\&P façade to verify its feasibility and validate the prototypes; 
3. Testing phases-The objective is to validate the performances of the P\&P façade system.

\section{Results}

\subsection{Design Phase}

The RenoZEB envelope renovation system (Figure 1a) is composed of three different layers: (1) the existing wall, which is not dismantled during retrofitting; (2) the cavity, which guarantees the connection between the existing wall and new RenoZEB P\&P façade module hosting the brackets and additional insulation; (3) the RenoZEB P\&P façade module.

The RenoZEB façade includes an aluminum frame and membranes that allow the incorporation of vapor resistance, water and air tightness, insulation, passive and active technologies (windows, solar collectors, and PV panels), and an external cladding material that can be customized building by building. The final façade system is the consequence of previous considerations and different preliminary solutions (Figure 1b). Thermal calculations and simulations of interstitial condensation have been carried out to meet specific needs and fulfill the requirements of the two demo buildings of the RenoZEB projects: Voru and Durango.

The developed façade system design has been applied for 5 different unit typologies:

- Opaque Unit-Curtain wall façade with customizable cladding system (fiber cement, cement board, wood panel, etc.) (Figure 1c);

- Window Unit-Curtain wall façade, which integrates the window frame unit and shading systems such as roller shutters or venetian blinds;

- Solar Thermal Collector Unit-Curtain wall façade with a water thermal solar collector, with water to be used for DHW to allow higher temperatures;

- PV Panel Unit-Curtain wall façade with a PV;

- Smart-IoT Unit-Curtain wall façade with sensors and actuators.

\begin{tabular}{|c|c|}
\hline EXISTING WALL \\
\hline CAVITY \\
RenOZEB \\
PREFABRICATED \\
PANEL
\end{tabular}

(a)

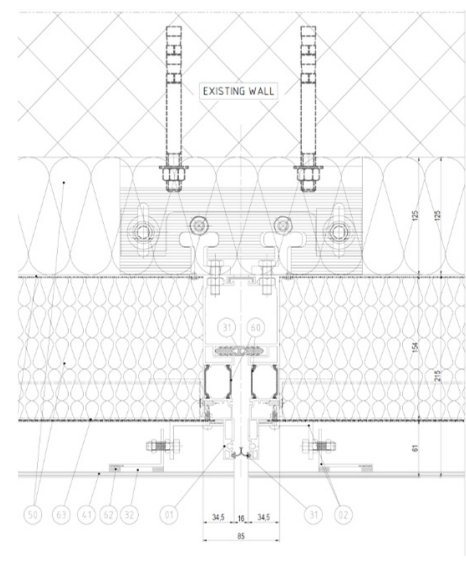

(b)

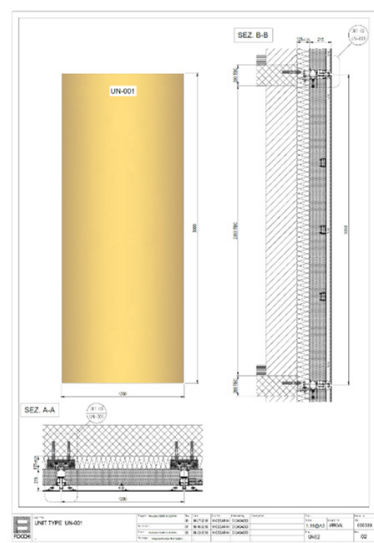

(c)

Figure 1. RenoZEB façade system development: (a) conceptual drawing showing the three different layers; (b) technical drawing showing the final solution of the façade system; (c) technical drawing of the opaque unit.

\subsection{Prototyping Phase}

The prototyping phase is a crucial phase in the technological development of the façade system, since it involves the verification of the correctness of the façade system. A dedicate team from the Focchi company, which was responsible for prototypes, manufactured and assembled the unit typologies (Figure 2). 


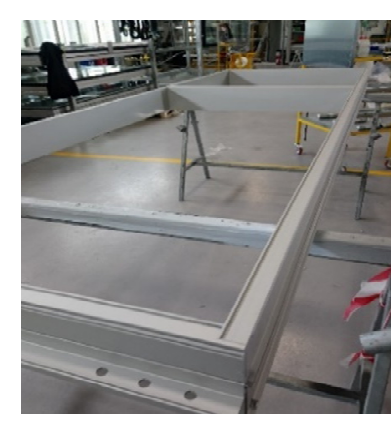

(a)

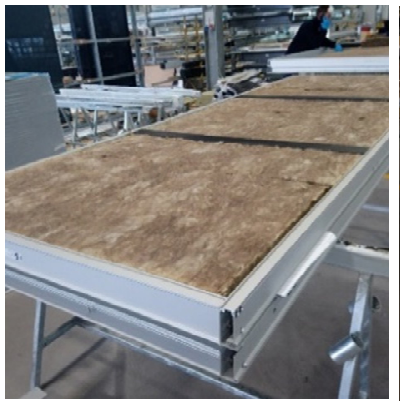

(b)

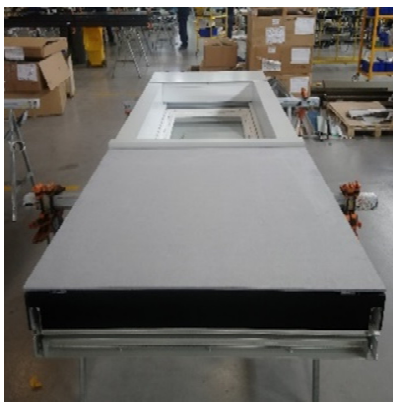

(c)

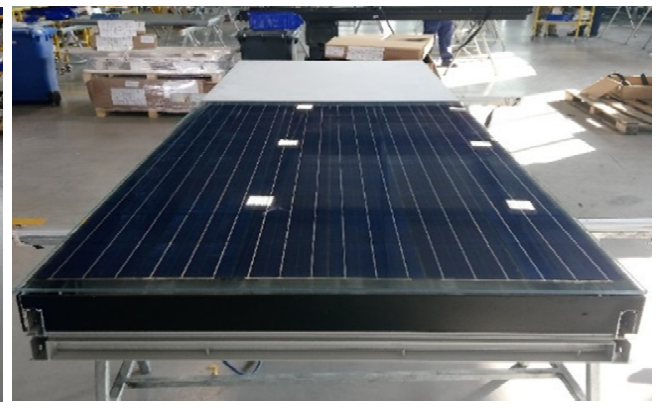

(d)

Figure 2. Manufacturing of façade system prototypes: (a) assembling the frame profile; (b) filling the frame with the mineral wool; (c) window unit; (d) PV panel unit.

\subsection{Testing Phase}

The tests conducted (Table 1) for the façade system were divided in two categories:

1. Acoustic (Figure 3a), performances (Figure 3b), and fire (Figure 3c) tests: These were conducted in the laboratory by a third-company expert, followed by certification to validate the solution;

2. Real environment tests: The RenoZEB modular façade was installed, monitored, and tested in a controlled safe environment (KUBIK), namely a test facility owned by Tecnalia R\&I (Figure 4). The aim was to validate the energy performance of the façade system by comparing the predicted and monitored results and to validate the installation procedure and generate video content for training activities.

Table 1. List of the conducted tests.

\begin{tabular}{|c|c|c|}
\hline Tests and Simulations & Test Conducted & Mock-Up \\
\hline Thermal Behavior (EN13788) ${ }^{1}$ & ISO EN 9869: 2014 standard & Design and Kubik \\
\hline Heat bridges and condensation risks & EN 15026:2007 2 & Design and Kubik \\
\hline Acoustic improvement of existing envelope & $\begin{array}{l}\text { UNI EN ISO 16283-3:2016/EC 1-2016/EC } \\
\text { 2-2016 and UNI EN ISO 717-1:2013 }\end{array}$ & Acoustic Mock-Up (AMU) \\
\hline $\begin{array}{l}\text { Watertightness of joints (protection against } \\
\text { driving rain (EN12865:2002) }\end{array}$ & $\begin{array}{l}\text { EN ISO 13830:2005 Curtain Wall } \\
\text { façade-CE for façade }\end{array}$ & Performance Mock-Up (PMU) \\
\hline $\begin{array}{l}\text { Wind load resistance (ETAG 034-ER4-Safety } \\
\text { in use) }\end{array}$ & $\begin{array}{l}\text { EN ISO 13830:2005 Curtain Wall } \\
\text { façade-CE for façade }\end{array}$ & Performance Mock-Up (PMU) \\
\hline $\begin{array}{c}\text { Reaction to fire (EN 13501-1) (Test under EN } \\
13823 \text {, classification SBI) }\end{array}$ & $\begin{array}{l}\text { EN 13501-1-Indication about Reaction } \\
\text { to fire classification }\end{array}$ & Fire Mock-Up (FMU) \\
\hline Fire resistance (EN1364-3 and EN 1364-4) & Not applicable in ventilated façade & - \\
\hline
\end{tabular}

${ }^{1}$ Hygrothermal performance of building components and building elements-Calculation methods (ISO 13788:2012) and EN ISO 100772:2008 and EN ISO 6946; ${ }^{2}$ Hygrothermal performance of building components and building elements-Assessment of moisture transfer by numerical simulation.

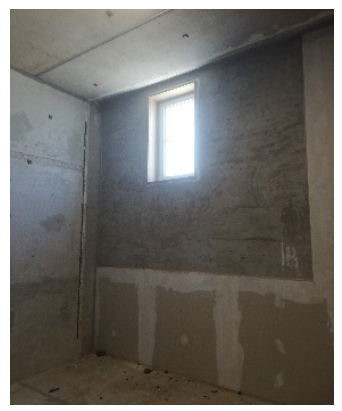

(a)

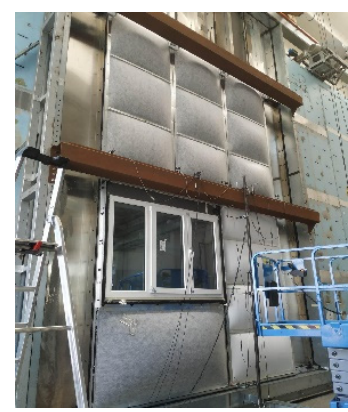

(b)

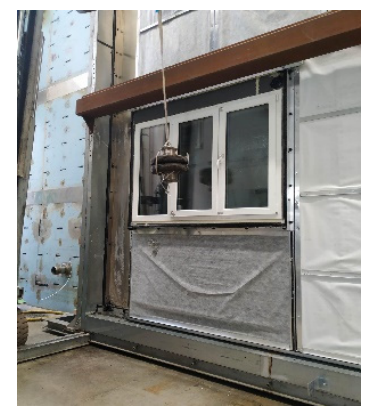

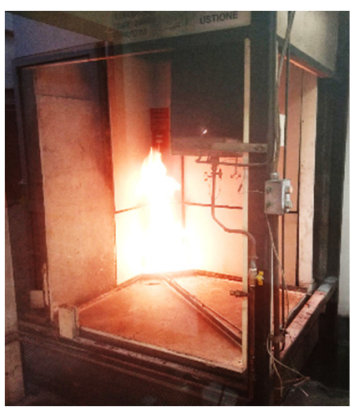

(c)

Figure 3. Testing activities: (a) AMU—Acoustic chamber ; (b) PMU—impact test; (c) FMU—fire test. 

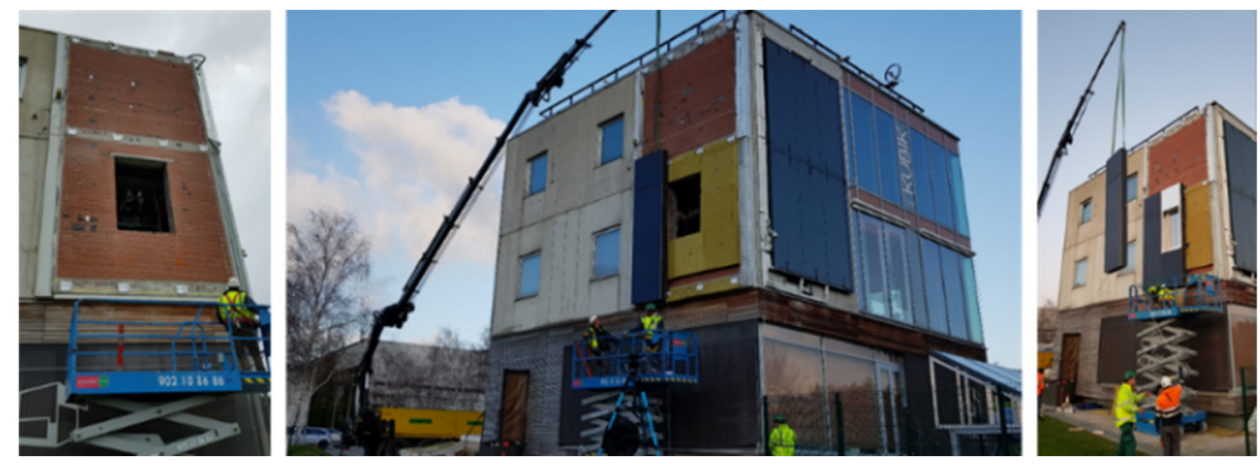

Figure 4. KUBIK real environment test.

\section{Discussion}

The performance achieved for the testing activities revealed that the RenoZEB façade system is in line with current building envelope standards for curtain wall façade solutions. The PMU met all standard requirements (13830:2005), while the AMU showed a result of $42 \mathrm{~dB}$, which is the required standard. Further, the FMU revealed a potential classification of B-s1-d0. Regarding KUBIK, the RenoZEB P\&P façade installation proved the overall correctness of the design. In addition, the real monitored transmittance value was $0.28 \mathrm{~W} / \mathrm{m}^{2} \mathrm{~K}$, in comparison to the existing value of $1.47 \mathrm{~W} / \mathrm{m}^{2} \mathrm{~K}$.

\section{Conclusions}

In accordance with the achieved results, the effectiveness of the RenoZEB façade system was demonstrates. This could be considered a valuable solution for the retrofitting of existing building stock. Indeed, its application in demo buildings, outside of the scope of this paper, demonstrated the great potential of the RenoZEB P\&P façade from architectural, technological, and energetic points of view.

Author Contributions: Conceptualization, A.P.; methodology, A.P.; validation, A.P.; formal analysis, M.V., A.U., A.P., L.V., A.B., O.C. and S.M.; investigation, M.V., A.U., A.P., L.V., A.B., O.C. and S.M.; resources, M.V., A.U., A.P., L.V., A.B., O.C. and S.M.; data curation, M.V., A.U., A.P., L.V., A.B., O.C. and S.M. writing-original draft preparation, L.V. and A.P.; writing-review and editing, A.P., L.V., A.U. and M.V.; visualization, A.P. and L.V.; project administration, M.V.; funding acquisition, M.V. All authors have read and agreed to the published version of the manuscript.

Funding: This research has received funding from the European Union's Horizon 2020 research and innovation program under Grant Agreement No. 768718.

Acknowledgments: The authors want to thank the RenoZEB partners for the fruitful discussions and collaboration.

Conflicts of Interest: The authors declare no conflict of interest.

\section{References}

1. Anđelković, A.S.; Kljajić, M.; Macura, D.; Munćan, V.; Mujan, I.; Tomić, M.; Vlaović, Ž.; Stepanov, B. Building Energy Performance Certificate-A Relevant Indicator of Actual Energy Consumption and Savings? Energies 2021, 14, 3455. [CrossRef]

2. RenoZEB. RenoZEB in a Nutshell. Available online: https://renozeb.eu/about/renozeb-in-a-nutshell.html (accessed on 16 November 2020).

3. Pracucci, A.; Magnani, S.; Vandi, L.; Casadei, O.; Uriarte, A.; Bueno, B.; Vavallo, M. An Analytical Approach for the Selection of Technologies to Be Integrated in a Plug\&play Façade Unit: The RenoZEB Case Study. Proceedings 2021, 65, 29. [CrossRef] 